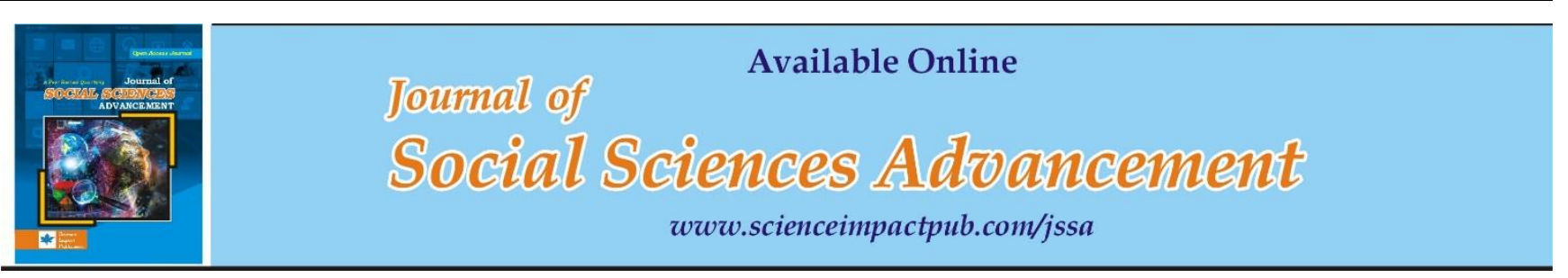

\title{
TRADE DETERMINANTS BETWEEN PAKISTAN AND UNITED ARAB EMIRATE: A TIME SERIES ANALYSIS
}

\author{
Muzzafar Ali' ${ }^{1}$, Raheela Khatoon'1 , Muhammad Munwar Hayat ${ }^{1}$ and Iqbal Javed $^{1}$ \\ ${ }^{1}$ Department of Economics, University of Lahore Sargodha Campus, Sargodha, Pakistan
}

\begin{abstract}
Economic efficiency in production of commodities depends mainly on technological development, geographically location, capital, availability of natural resources, social setup, skilled labours, customs, some economic and financial priorities. Pakistan mostly traded with China, United Arab Emirates, United State of America and Saudi Arabia. The current study is aimed to estimate the impact of different factors affecting the bilateral trade of Pakistan with United Arab Emirates. The study used annual time series data for the period from 1988 to 2019. In this analysis total bilateral trade is used as dependent variable while population, Gross Domestic Product (GDP), inflations and exchange rate of Pakistan and United Arab Emirates (UAE) were used as independent variables. ARDL approach was applied to check the relationship among the variables. The study finds short run and long run significant relationship among the variables. The gaps in business related plans \& polices and entrepreneurship deficiency have prevented the country to cope with the technology advancements. Further this gap is also responsible for greater export diversification and putting of Pakistan to accomplish higher value addition. Incompetent and disorganized firms are trying to get tax exemptions and dispensation through lobbying, whereas new emerging efficient and dynamic firms are also not given confidence to take a part in market.
\end{abstract}

Keywords: Determinants; Trade; Time series analysis; United Arab Emirates; Pakistan

Corresponding Author: Iqbal Javed, Email: iqbaljaved_uaf@hotmail.com

(C) The Author(s) 2020.

\section{INTRODUCTION}

Trade is an engine of economic growth in the view of classical and modern economists. Due to international trade necessary and cheaper goods are available to the people of world. Comparative advantages are also achieved (Majeed, 2006). International trade plays significant role to earn foreign exchange and economic development. Classical and modern economists believe that international trade is necessary for economic growth and economic development (Jadoon et al., 2018). Export can be defined as selling the goods or services produced in a country to another country as an international trade. The main concern on exporting was always its benefits to the international trade and the country and also its risk on the possibility that certain domestic industries could be harmed by foreign completion (Yee et al, 2016). Exports play crucial role in the growth of any country and major factor describing economic health of any country. Since in 1970 the relationship between exchange rate volatility and export was investigated. When exchange rate moves from flexible to fixed exchange rate after Bretton Wood agreement in 1972-1973 (Ahmad et al., 2017).

One of basic principle in external trade is that a country should buy goods and services from another country which has lowest prices and sell their goods and services to those which has the highest prices. External trade has been beneficial for growth (Afanso, 2001). It has an important contribution in development process of a nation's economic progress. Trade is the only way to change the economic, social and political condition of a country. Export and import both are equally vital. Country with more trade gain high income (Noguer and Siscart, 2005). A country is importing raw materials, intermediate and capital goods to boost its production and to develop export if such commodities are not internally available in the country. For meeting the need of domestic demand of consumer goods, imports are necessary. Export trade is essential to bridge the gap of external exchange and curtail dependency on external trade. It also increases the import capacity. For developing industrialization and overall economic growth, an increase in import capacity is crucial. So trade is vital for rapid economic development and growth.

There are forty-four landlocked countries in the world. Landlocked countries are those countries which have no territorial access to limited border crossings, seas, and transit dependence. Landlocked countries bear some economic hurdles because of dependence on who has ports (Lahiri and Masjidi, 2012). These countries bear high trade transaction costs due to its remoteness. Afghanistan is one of the landlocked countries. It is the southwest Asian landlocked country. Afghanistan uses Pakistan and Iranian land for external trade. It is suffering from war and 
political instability since Soviet invasion. Afghanistan have border lines with 6 neighbour countries, Iran, Pakistan, Uzbekistan, Turkmenistan, China and Tajikistan. It is a gateway to other landlocked countries in the north. Pakistan and Iranian seaports are situated in its southern area. For Central Asian countries like Russia, it is the shortest route to open sea. For Pakistan it is also a primary route for trade to Central Asian countries. Afghanistan is an open trade route to central Asia through roads from its northern borders. Routes through Afghanistan offer the central Asian Republics (CARs) shorter distances to the sea than land link to the Black Sea, Europe and China. The Afghan route through Pakistan, Karachi via Quetta is also a shortest route from sea to the Central Asian Republics.

Bilateral trade is a trade of goods and services between two countries. In this type of trade, distance is about inversely proportional (Fink et al., 2002). Bilateral trade is one of the three dimensions of Pakistan Afghanistan trade. It is a trade of goods and services between two countries. Trade between these two countries are very important due to they are Islamic and neighbouring. Pakistan is situated near open sea which is advantageously better for trade. Pakistan is an important trade partner with Afghanistan. Trade between Afghanistan and Pakistan is of threedimensional structure that includes: trade through transit, trade through uncontrolled channels, bilaterally recognized trade. Transit Trade, being saturated discussed in many articles and research works, needn't be discussed here. Currently, the practice of Free Trade Agreements is getting immense importance among emerging economies. It urges neighbouring states must persuade their local partners to establish FTAs on regional bases to reduce the cost of business, imports and exports for the states being geographically linked. It is very important to take benefits from CAREC i.e. Central Asian Economic Cooperation (Khan, 2016). The relation of trade between these two countries in few previous years, is not good despite strong cultural ties (Shahab and Bhatnagar, 2015). The tradition between the two countries is same in history, culture and religion (Hasan,1962). From the time of independence of Pakistan, many political controversies threatened the relation between the two neighboring countries. The bilateral trade between the two countries has increased from 2001 when United State started war against terror (Shabbir and Ahmad, 2015). Bilateral trade has increased from Rs 16,315,232 in 2002-03 to Rs 184,948,201 in 2010-11. It has been dropped down to Rs 97,210,853 in 2016-17 (Pakistan Bureau of Statistics). Some reasons for this decline are reduction in NATO supply shipments, political instability, customs delays and others. Although some trade has been started between these two neighbours.

\section{REVIEW OF LITERATURE}

Afonso (2001) says that for growth trade liberalization is beneficial. It is particularly for developed countries, because trade liberalization affects a rate of internal innovation. Developing countries mostly do investments in research only for the purpose of convergence. For low developed countries, who only invest in research in development for the convergence. The sharpness of dynamic effects depends simultaneously on the geographic structure of open trade on the structure and sharpness of open trade on capacity for domestic technological adaptation. Coulibaly and Fontagné (2006) analyzed the effect of geography on south to south trade. They argued that a global disadvantage faced by landlocked countries particularly developing countries. In gravity model, there is cogent effect of remoteness from ocean, remoteness from road and GDP of the trading partners on trade. Lahiri and Masjidi (2012) described that landlocked countries bear various economic hurdles because of dependence on neighbours who has ports. They are of the view that a landlocked nation with more neighbours is in better position to make some minor adjustment in policies to gain from port owner nations. According to MacKellar et al. (2000) landlocked countries faces many problems than coastal countries, but it does not mean that they have slower growth. Their studies reveal that in $1962-$ 92, developing land locked countries grow slower at the rate of 1.5 percent per year than not- landlocked. They point out three policies for development as mention next. (a) Landlocked nation pay proper attention to transport. (b) They prepare such developmental policies which are not relying on physical transport. (c) They should receive proper protection for world's community against their port owner neighbors.

Oskooee and Cheema (2009) analysed that on disaggregated bilateral trade data of Pakistan with 13 trading partners. They identified some facts of short run impact of real exchange rate on trade by Bound-testing approach. They also found that this is a positive and significant relationship of real exchange rate and trade balance in long run in 50 percent of trading partners. The study reveals that not all the trading partners affected by Pakistani currency depreciation. Filer (2011) says that an integrated trade model is a single frame work for trade for wealthy nations as well as trade of different income level nations. Trade among wealthy nations occurs basically in differentiated commodities and trade of wealthy nation with poor nations occurs across sectors. The gravity model theoretical foundation is based on intra industry trade. Porojan (2001) analyzed for gravity model special econometric technique for estimation. When we apply it to the data, so changes occur in magnitude and statistical significance of parameters. It also vanished the bias when ignored spatial effect.

Jean (1998) says that for the claim of bilateral trade result to business cycle, there are three factors. Variables are respond simultaneously, potentially time invariant. (b) It would react to bilateral trade in the non-availability of independent monetary policy. Omni presence of the hypothesis is unclear that fixed exchange rate regime will stimulate exchange rate. Baxter and Kouparitsas (2006) said that bilateral trade was positively related to fix exchange rate while the exchange rate volatility is negatively related to bilateral trade is a weak evidence. They described the 
determinants of bilateral trade are (a) the endowment product of two trading partners is positively related to bilateral trade. (b) When the developmental stage of the countries is same, the bilateral trade was low. Noguer and Siscart (2005) argued that a country which has more trade gain high income level. 1 percent raise in the trade of GDP of country leads about 1 percent raise of that country per capita income. The countries have lower income when they have less open trade because of geographical factors. The composition and trade volume affect by the restricted trade policies. Disdier and Head (2008) described that distance is about inversely proportional to bilateral trade because the mean elasticity is 0.9 . In the estimated distance effect, a great variation occurs. It shows 2 percent explained by sampling error. Meta regression shows the estimated distance effect.

Fink et al. (2002) analyzed that there is variation which occur internationally in communication cost, have an important influence on trade. The communication costs have large impact on differentiated than homogeneous products. The rate of communication cost is to ease the progress of global yielding chains. It is affecting the world's unification pattern. This study plays its contributory role in the area of bilateral trade between Pakistan and UAE and estimated the impact of different variables on bilateral trade between Pakistan and United Arab Emirates. The researcher is analysing deep about the bilateral trade among both the countries. The demand from both sides have also been increased.

\section{METHODOLOGY}

This study will use the following methodology/ techniques used by earlier researchers. The study will adopt the ARDL model "An empirical analysis of Pakistan and United Arab Emirates bilateral trade" with some new variables are added in the model. The current study used the secondary data of different variable from 1988-2019. The data were taken from the World Bank and international trading centre. For the analysis, the study will use the following gravity model.

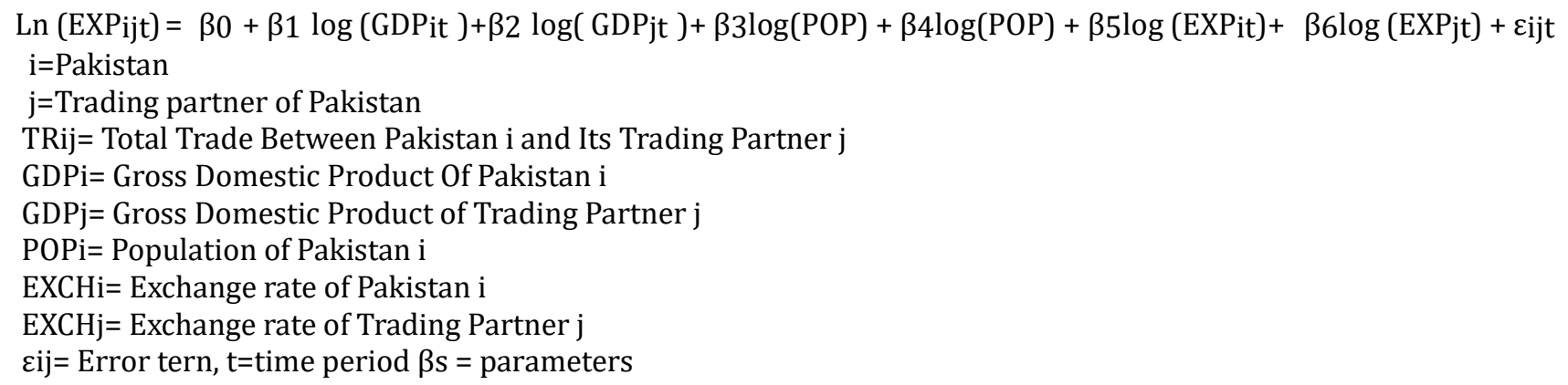

\section{RESULTS AND DISCUSSION}

Table 1: Short Run ARDL Model

\begin{tabular}{lrrrr}
\hline Variable & Coefficient & Std. Error & t-Statistic & Prob.* $^{*}$ \\
\hline LOG(EXPIJ(-1)) & 0.015852 & 0.139996 & 0.113234 & 0.9108 \\
LOG(GDPI) & -0.440200 & 0.555221 & -0.792837 & 0.4360 \\
LOG(GDPJ) & 0.467677 & 0.332525 & 1.406443 & 0.1730 \\
LOG(EXCI) & 0.074129 & 0.264036 & 0.280755 & 0.7814 \\
LOG(EXCI(-1)) & 1.082519 & 0.297380 & 3.640190 & 0.0014 \\
LOG(EXCJ) & 490.9832 & 489.3751 & 1.003286 & 0.3262 \\
LOG(EXCJ(-3)) & 84.49153 & 18.53614 & 4.558206 & 0.0001 \\
LOG(PI) & -4.249378 & 1.404568 & -3.025398 & 0.0060 \\
LOG(PJ) & 0.611923 & 0.403686 & 1.515840 & 0.1432 \\
C & -1846.519 & 513.5539 & -3.595570 & 0.0015 \\
R-squared & 0.984253 & Durbin-Watson stat & 2.021088 & \\
Adjusted R-squared & 0.975353 & Prob(F-statistic) & 0.000000 & \\
\hline
\end{tabular}

These are the results of short run ARDL model. Akaike info criteria has been used in this model. The variables like EXPij Prob value (0.9108), GDPI Prob value (0.4360) which shows insignificant and negative impact on dependent variable. GDPJ Prob value (0.1730) shows the positive impact, EXCI (-1) Prob value (0.001) which explained the positive and significant impact, EXCJ(-3) Prob value (0.00),PI Prob value(0.006),PJ Prob value (0.14) Constant Prob value $(0.0015)$ is significant. 
Table 2: ARDL Bound Test

\begin{tabular}{lll}
\hline Test Statistic & Value & $\mathrm{K}$ \\
\hline F-statistic & 9.955253 & 6 \\
Critical Value Bounds & & \\
Significance & I0 Bound & I1 Bound \\
$10 \%$ & 2.12 & 3.23 \\
$5 \%$ & 2.45 & 3.61 \\
$2.5 \%$ & 2.75 & 3.99 \\
$1 \%$ & 3.15 & 4.43 \\
\hline
\end{tabular}

The value of F-statistic (9.9552) is higher than the upper Bound (3.61) at 5 percent level of significance. So we can conclude that there is a long run relationship exist between the variables.

\section{ARDL Long Run Results}

Table 3: Long Run Coefficients

\begin{tabular}{crrrr}
\hline Variable & Coefficient & Std. Error & t-Statistic & Prob. \\
\hline LOG(GDPI) & -0.110554 & 0.571875 & -0.193318 & 0.8484 \\
LOG(GDP) & 0.695490 & 0.320951 & 2.166965 & 0.0408 \\
LOG(EXCI) & 2.859836 & 0.326443 & 8.760585 & 0.0000 \\
LOG(EXC)) & 1487.851721 & 363.390433 & 4.094361 & 0.0004 \\
LOG(PI) & 521.838246 & 76.171896 & 6.850798 & 0.0000 \\
LOG(PJ) & 85.514664 & 12.280151 & 6.963649 & 0.0000 \\
C & -2637.040210 & 478.857044 & -5.506947 & 0.0000 \\
\hline
\end{tabular}

This tale shows the results of ARDL Model. Total export value (TRij) of Pakistan is a dependent variable and other variables are independent variables in the study. All the variables are significant in the long run except GDPi. If GDPj increase by 1 Percent, the EXPij will increase by 0.69 percent. If EXCi increase by 1 percent, then the EXPij will increase by 2.85 percent. While EXCj, Pi, Pj have significant and positive relationship with the dependent variable. The increase in GDP of market of United Arab Emirates will cause a decrease in the share of import of market of UAE from Pakistan. The growing number of persons existing in Pakistan shows a negative and significant impact on Pakistan's exports to its Trading Partner United Arab Emirates. More population is assumed to consume more and left behind less surplus quantity for exports. Population have a positive and significant impact on Pakistan's exports to United Arab Emirates.

\section{CONCLUSION}

Gross domestic product of Pakistan has negative and insignificant impact on Pakistan's export to United Arab Emirates. Gross Domestic Product of United Arab Emirates has a positive impact on exports of Pakistan to the United Arab Emirates. In spite of Pakistan trade's liberalization regime, Pakistan did not yet utilize these opportunities to get profit and originating from the development in international trade from last decade. The industrial sector of Pakistan is initially cultivated under import exchange bias with the considerable support of government, has not met to global market competitiveness. The gaps in business related plans \& polices and entrepreneurship deficiency have prevented the country to cope with the technology advancements. Further this gap is also responsible for greater export diversification and putting of Pakistan to accomplish higher value addition. Incompetent and disorganized firms are trying to get tax exemptions and dispensation through lobbying, whereas new emerging efficient and dynamic firms are also not given confidence to take a part in market.

\section{REFERENCES}

Afonso, O. (2001). The impact of international trade on economic growth. Investigação-Trabalhos em Curso, 106.

Arora, S., Bahmani-Oskooee, M., \& Goswami, G. (2003). Bilateral J-curve between India and her trading partners. Applied Economics, 35(9), 1037-1041.

Bahmani-Oskooee, M., \& Cheema, J. (2009). Short-run and long-run effects of currency depreciation on the bilateral trade balance between Pakistan and her major trading partners. Journal of Economic Development, 34(1), 19.

Baxter, M., \& Kouparitsas, M. A. (2006). What determines bilateral trade flows? (No. w12188). National Bureau of Economic Research.

Coulibaly, S., \& Fontagné, L. (2006). South-South trade: geography matters. Journal of African Economies, 15(2), 313341.

Disdier, A. C., \& Head, K. (2008). The puzzling persistence of the distance effect on bilateral trade. The Review of Economics and statistics, 90(1), 37-48.

Fink, C., Mattoo, A., \& Neagu, I. (2002). Assessing the impact of communication costs on international trade. The World Bank. 
Hasan, Khurshid,(1962), Asian Survey volume 2, No.7 September, 1962, p.no.14_24

Hutchinson, W. K. (2005). " Linguistic distance" as a determinant of bilateral trade. Southern Economic Journal, 1-15. Irwin, D. A., \& Terviö, M. (2002). Does trade raise income?: Evidence from the twentieth century. Journal of International Economics, 58(1), 1-18.

Jean, I. (1998). Fluctuations, Bilateral Trade and the Exchange Rate Regime (No. 9906). Université de Lausanne, Faculté des HEC, Département d'économie.

Lahiri, B., \& Masjidi, F. K. (2012). Landlocked countries: A way to integrate with coastal economies. Journal of economic integration, 505-519.

MacKellar, L., Wörgötter, A., \& Wörz, J. (2000). Economic development problems of landlocked countries.

Noguer, M., \& Siscart, M. (2005). Trade raises income: a precise and robust result. Journal of international Economics, 65(2), 447-460.

Porojan, A. (2001). Trade flows and spatial effects: the gravity model revisited. Open economies review, 12(3), 265280.

Publisher's note: Science Impact Publishers remain neutral with regard to jurisdictional claims in published maps and institutional affiliations.

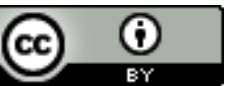

Open Access This article is licensed under a Creative Commons Attribution 4.0 International License, which permits use, sharing, adaptation, distribution and reproduction in any medium or format, as long as you give appropriate credit to the original author(s) and the source, provide a link to the Creative Commons license and indicate if changes were made. The images or other third-party material in this article are included in the article's Creative Commons license, unless indicated otherwise in a credit line to the material. If material is not included in the article's Creative Commons license and your intended use is not permitted by statutory regulation or exceeds the permitted use, you will need to obtain permission directly from the copyright holder. To view a copy of this license, visit https://creativecommons.org/licenses/by/4.0/.

(C) The Author(s) 2020 